\title{
Suitability of Clay Water Filter for the Removal of Nephrotoxic Constituents in CKDu Prevalent Areas
}

\author{
Dulshan S.Y.S., Sudasinghe M.I., Jayaweera M.W.*, Manatunge J.M.A., \\ Gunawardane W.B.
}

\author{
Department of Civil Engineering, University of Moratuwa, Sri Lanka \\ *maheshjayaweera@gmail.com
}

\begin{abstract}
Consumption of water composed of different nephrotoxic constituents such as Hardness, Fluoride, Cadmium, and Aluminum has manifested to be triggering causal factors of Chronic Kidney Disease of unknown etiology $(\mathrm{CKDu})$ and non-nephrotoxic health hazards. Hence, it is a prerequisite to remove these nephrotoxic constituents from water to levels less than the permissible drinking water guideline values. Thus, an introduction of clay water filters has been reckoned to be a solution, which will provide safe drinking water to people in CKDu prevalent areas. This filter media is composed of clay and shifted rice husk mixture. The suitability of the clay water filter unit to remove nephrotoxic constituents is, however, has not been comprehensively investigated. Therefore, the present study focuses on investigating the suitability of the clay water filter unit in the removal of nephrotoxic constituents effectively and efficiently from potable water. Feed water was, therefore, synthesized simulating wet (October \& November) and extreme wet (December) seasons in the dry zone in Sri Lanka, in which the feed water constituted of Hardness of 350 and $150 \mathrm{mg} / \mathrm{l}$, Fluoride of 3 and $1 \mathrm{mg} / \mathrm{l}$, Cadmium of 1 and 1 $\mathrm{mg} / \mathrm{l}$ and Aluminum of 1 and $1 \mathrm{mg} / \mathrm{l}$ for both wet and extreme wet seasons respectively. With the assumption that four members of a family consume 81 of water per day, samples were collected and analyzed. Average concentration values of the treated water were determined as Hardness of 340 and $148 \mathrm{mg} / \mathrm{l}$, Fluoride of 0.92 and $0.87 \mathrm{mg} / \mathrm{l}$, Cadmium of 0.69 and $0.58 \mathrm{mg} / \mathrm{l}$, and Aluminum of 0.74 and $0.67 \mathrm{mg} / \mathrm{l}$ during wet and extreme wet seasons. Hardness values did not comply with drinking water guideline values of $250 \mathrm{mg} / \mathrm{l}$ (SLS- 613:2013) during the wet season and Cadmium of $0.003 \mathrm{mg} / \mathrm{l}$ (WHO Guideline) during both seasons. Aluminum and Fluoride values complied with WHO permissible drinking water guideline values of $0.9 \mathrm{mg} / \mathrm{l}$ and $0.6-1.5$ $\mathrm{mg} / \mathrm{l}$ respectively. The XRD, FTIR, ESEM-EDX analyses of filter media of the clay filter unit confirmed that the filter media composed of clay and non-clay minerals mainly, silicon oxide, quartz, albite, gottardiite and salicylic acid, with prominent elements of aluminum, calcium, magnesium, oxygen, silicon, and sodium. In such minerals, functional groups such as $\mathrm{Si}-\mathrm{O}-\mathrm{Si}$, Si$\mathrm{O},-\mathrm{OH},-\mathrm{COOH}$ and $\mathrm{Si}-\mathrm{OH}$ were found to be the most dominant ligands that can form complexes with ions in water. $\mathrm{Al}^{3+}$ ions showed strong interactions with such functional groups more than $\mathrm{Ca}^{2+}, \mathrm{Mg}^{2+}$ and $\mathrm{Cd}^{2+}$ ions did, resulting in a better removal of Aluminum through the formation of covalent bonds between Aluminum and ligands. Complexation of $\mathrm{F}^{-}$with $\mathrm{Al}^{3+}, \mathrm{Ca}^{2+}$, and $\mathrm{Mg}^{2+}$ ions in clay minerals was too seen indicating an excessive removal of Fluoride in the water. However, $\mathrm{Ca}^{2+}, \mathrm{Mg}^{2+}$, and $\mathrm{Cd}^{2+}$ showed poor interactions with ligands resulting in an ineffective and an inefficient removal of $\mathrm{Ca}^{2+}, \mathrm{Mg}^{2+}$ and $\mathrm{Cd}^{2+}$ ions in water. Hence, it could be inferred that the use of the clay filter unit is not a promising solution to remove high concentrations of $\mathrm{Ca}^{2+}$, $\mathrm{Mg}^{2+}$ and $\mathrm{Cd}^{2+}$ ions from water in CKDu prevalent areas.
\end{abstract}

Keywords: Aluminum, Cadmium, Drinking water, Fluoride, Hardness

Proceedings of the $22^{\text {nd }}$ International Forestry and Environment Symposium 2017 of the Department of Forestry and Environmental Science, University of Sri Jayewardenepura, Sri Lanka 